\title{
Antibacterial Activity of 2 '-hydroxy-4', 6 'dimethoxychalcone
}

\section{Aktivitas Antibakteri Senyawa 2'-hidroksi-4',6' dimetoksikalkon}

Wiwit Sepvianti*, Serafica Btari Christiyani Kusumaningrum

\section{Intisari}

Kalkon merupakan senyawa flavanoid rantai terbuka yang memiliki beragam aktivitas farmakologis diantaranya sebagai antioksidan, ${ }^{2}$ antibakteri, ${ }^{3}$ antiinflamatori dan antikanker. ${ }^{4}$ Senyawa $2^{\prime}$-hidroksi4',6'-dimetoksikalkon telah dilaporkan memiliki aktivitas antikanker yang sangat baik dan bersifat selektif, yaitu hanya aktif mematikan sel kanker namun tidak mematikan sel normal. ${ }^{5}$ Aktivitas senyawa 2'-hidroksi-4',6'-dimetoksikalkon yang baik terhadap sel kanker diharapkan juga bekerja pada bakteri. Penggunaan alkohol sebagai desinfektan pada proses aftap memberi resiko lisis darah, sehingga diperlukan senyawa kimia yang efektif sebagai antibakteri namun minim resiko melisiskan darah. Aktivitas antibakteri senyawa kalkon diuji menggunakan metode difusi agar dengan sumuran, zona bening yang terbentuk disekitar sumuran menunjukan aktivitas senyawa kalkon dalam menghambat pertumbuhan bakteri. Pada penelitian ini seluruh larutan kalkon dalam variasi konsentrasi $2 ; 4 ; 8 ; 10$; dan $20 \%$ tidak menunjukkan aktivitas penghambatan pertumbuhan bakteri, sedangkan pada sumuran yang diisi padatan kristal kalkon menunjukkan zona bening sekitar $1 \mathrm{~mm}$ sehingga dapat disimpulkan bahwa senyawa 2'-hidroksi-4',6'-dimetoksikalkon tidak memiliki aktivitas sebagai antibakteri.

Kata kunci: produk darah, antibakteri, kalkon

\section{Pendahuluan}

Produk darah merupakan salah satu sediaan obat yang sangat dibutuhkan dewasa ini, terutama bagi pasien yang menjalani terapi medis menggunakan produk darah seperti hemodialisis dan anemia kronik. ${ }^{6}$ Darah sebagai sediaan obat harus bebas dari kuman penyakit, karena baik virus maupun bakteri dapat ditransmisikan melalui transfusi darah. Hasil penelitian menunjukan bahwa kasus infeksi bakteri melalui transfusi darah lebih banyak dibandingkan infeksi virus dengan

Afiliasi Penulis

STIKes Guna Bangsa Yogyakarta

Korespondensi kepada

W. Sepvianti

wiwit.sepvianti01@gmail.com angka prevalensi infeksi bakteri mencapai 1: 1000 sedangkan prevalensi infeksi virus sebesar 1: 34.000. ${ }^{7}$ Beberapa upaya yang telah dilakukan untuk mengurangi kontaminasi bakteri pada produk darah adalah ketat dalam penggunaan desinfektan dalam serangkaian proses pengolahan darah, akan tetapi penggunaan alkohol dilaporkan memberi resiko lisis darah, sehingga diperlukan senyawa kimia yang efektif sebagai antibakteri namun minim resiko melisiskan darah. Pada penelitian ini akan dilakukan uji aktivitas antibakteri pada senyawa 2'-hidroksi-4',6'dimetoksikalkon terhadap bakteri gram positif: Staphylococcus aureus dan bakteri gram negatif: Escherichia coli. Senyawa ini diprediki memiliki potensi sebagai antibakteri dikarenakan mengikat gugus-gugus aktif seperti hidroksi dan metoksi. 


\section{Metode}

Uji aktivitas antibakteri senyawa 2'-hidroksi4',6'-dimetoksikalkon dilakukan dengan metode difusi agar dengan penentuan daya hambat dihitung dari zona bening yang terbentuk. Bakteri uji yang digunakan Escherichia coli dan Staphylococcus aureus.

Alat

Alat yang dibutuhkan pada penelitian ini yaitu seperangkat alat gelas steril, mikropipet, inkubator, hotplate dan autoklaf.

\section{Bahan}

Bahan yang digunakan pada penelitian ini yaitu media pertumbuhan bakteri nutrien broth, akuades, agar, alkohol 70\%, Brain-Heart Infusion (BHI), antibiotik, DMSO, kultur bakteri gram positif Staphylococcus aureus, serta kultur bakteri gram negatif Escherichia coli.

\section{Prosedur penelitian}

\section{Pembuatan larutan uji kalkon}

Larutan uji dibuat dengan melarutkan senyawa kalkon dalam DMSO, dengan variasi konsentrasi 2 , 4, 8, 10 dan $20 \%$.

\section{Sterilisasi alat}

Setiap alat harus disterilkan sebelum digunakan yaitu dengan cara dibungkus kertas dan dimasukkan dalam autoklaf pada $121^{\circ} \mathrm{C}$ dengan tekanan 15 psi selama 15 menit. Alat yang tidak tahan dengan panas disterilkan dengan alkohol $70 \%$.

\section{Pembuatan media alas}

Sebanyak 20 g serbuk agar dilarutkan ke dalam $1000 \mathrm{~mL}$ akuades. Kemudian larutan dipanaskan hingga serbuk agar larut sempurna. Selanjutnya disterilisasi menggunakan autoklaf pada suhu $121^{\circ}$ C dan tekanan 15 psi selama 15 menit. Setelah itu larutan didinginkan dan didiamkan di dalam lemari pendingin.

\section{Peremajaan bakteri}

Sebanyak 0,24 g NB dilarutkan ke dalam $30 \mathrm{~mL}$ akuades. Kemudian larutan tersebut dituang ke dalam 5 buah tabung reaksi dengan masing-masing tabung terdapat $6 \mathrm{~mL}$ larutan NB. Selanjutnya disterilisasi menggunakan autoklaf pada suhu $121^{\circ} \mathrm{C}$ dan tekanan 15 psi selama 15 menit. Setiap tabung diisi dengan $3 \mathrm{~mL}$ bakteri patogen yaitu
Staphylococcus aureus dan Escherechia coli. Setelah itu semua tabung dimasukkan ke dalam inkubator dan didiamkan selama 24 jam.

\section{Pembuatan media bakteri}

Ke dalam 20 buah Erlenmeyer 100 mL masingmasing dimasukkan 0,4 g NB dan 0,8 g agar, kemudian di tuang akuades sebanyak $50 \mathrm{~mL}$. Larutan tersebut dipanaskan hingga NB dan agar larut sempurna. Selanjutnya disterilisasi menggunakan autoklaf pada suhu $121^{\circ} \mathrm{C}$ dan tekanan 15 psi selama 15 menit. Setelah itu larutan didinginkan dan didiamkan di dalam lemari pendingin. Larutan dipanaskan kembali hingga encer dan didiamkan beberapa saat hingga larutan tidak terlalu panas. Selanjutnya setiap Erlenmeyer diisi dengan $500 \mu \mathrm{L}$ bakteri patogen yaitu Staphylococcus aureus dan Escherechia coli hasil peremajaan. Larutan agar dituang ke dalam cawan petri yang telah diisi media alas serta telah dipasang ring. Cawan petri kemudian ditutup dan didiamkan beberapa saat. Ring dicabut ketika agar sudah mengeras sehingga terbentuk sumuran agar.

Injeksi sampel dan pengukuran zona hambat

Ke dalam sumuran ditambahkan serbuk padat kalkon dan $150 \mu \mathrm{L}$ sampel uji pada konsentrasi 2, 4, $8,10,20 \%$ dengan kontrol positif chloramphenicol dan kontrol negatif DMSO. Masa inkubasi dilakukan selama 24 jam, selanjutnya dilakukan pengukuran zona hambat. Diameter zona hambat yang terbentuk diukur menggunakan jangka sorong untuk menentukan efektifitas antibakteri.

\section{Hasil \& Pembahasan}

Senyawa kalkon yang diujikan berbentuk padatan kristal murni dan larutan dalam beberapa konsentrasi, untuk membuat larutannya digunakan pelarut DMSO. Pelarut ini digunakan sebagai pelarut senyawa uji kalkon sekaligus kontrol negatif karena terbukti tidak dapat menghambat pertumbuhan bakteri sehingga zona hambat yang terbentuk merupakan murni zona hambat dari senyawa uji. Kontrol positif yang digunakan dalam uji ini yaitu antibiotik chloramphenicol yang dilarutkan dengan akuades steril. Chloramphenicol merupakan antibakteri pertama yang berspektrum luas, dengan mekanisme kerja menghambat sintesis protein dan bersifat bakteriostatik. 
Hasil uji aktivitas antibakteri senyawa 2'hidroksi-4',6'-dimetoksikalkon menggunakan metose difusi agar yang disajikan pada Tabel.1. menunjukkan bahwa senyawa senyawa 2'-hidroksi4',6'-dimetoksikalkon tidak memiliki aktifitas sebagai antibakteri baik pada bakteri gram positif: Staphylococcus aureus maupun bakteri gram negatif: Escherichia coli. Padatan kristal kalkon murni menunjukan keberadaan zona bening pada pertumbuhan bakteri Escherichia coli namun hanya sekitar $1 \mathrm{~mm}$ saja. Suatu senyawa yang zona penghambatan kurang dari $6 \mathrm{~mm}$ dinyatakan tidak aktif. $^{8}$

Senyawa 2'-hidroksi-4',6'-dimetoksikalkon yang mengikat gugus hidroksi dan metoksi pada ring $A$ semula diprediksi memiliki aktivitas yang baik sebagai antikanker. Namun, pada penelitian ini telah terbukti senyawa kalkon ini tidak berpotensi sebagai antibakteri. Gugus hidroksi memiliki kemampuan melarutkan lipid pada membran luar bakteri gram negatif, sehingga mampu membuat kerusakan membran yang menggangu fungsi pertahanan terluar bakteri. Bakteri akan kehilangan penyangga dan mengalami lisis. Akan tetapi kemungkinan posisi gugus hidroksi pada senyawa 2'-hidroksi-4',6'-dimetoksikalkon berada pada posisi yang cukup sterik atau tidak bebas menyebabkan interaksinya dengan lipid pada membran bakteri tidak optimal, sehingga senyawa ini tidak dapat berfungsi sebagai antibakteri. Hal ini bersesuaian dengan pernyataan Nur et al (2017) bahwa sifat antibakteri senyawa kalkon tergantung pada jenis substituen dan posisi substituen yang terikat pada kedua cincin aromatiknya.

\section{Kesimpulan}

Berdasarkan hasil peneltian yang telah dilakukan maka dapat disimpulkan bahwa senyawa 2'-hidroksi-4',6'-dimetoksikalkon tidak memiliki aktivitas antibakteri pada bakteri gram positif maupun bakteri gram negatif.

\section{Apresiasi}

Ucapan terimakasih disampaikan kepada DIPA Kopertis Wilayah $\mathrm{V}$ yang telah mendukung dengan Dana Bantuan Penelitian dengan nomor kontrak 017/LPPM-GB/PEN/VI/2018

\section{Bibliografi}

1. Mai, C.W., Yaeghoobi, M., Ab-Rahman, N., Kang, Y.B., and Pichika, M.R., 2014, Chalcones with Electron-with Drawing and Elektron-Donating Substituens: Anticancer Acitivity Against TRAlL Resistant Cancer Cells, Structure-Activity Relationship Analysis and Regulation of Apoptotic Protein, Eur. J. Med. Chem., 77, 378-387.

2. Oldoni, T.L., Cabral, I.S., Regitano, M.A.B., Rosalen, P.L., and Ikegaki, M., 2011, Isolation and Analysis of Bioactive Isoflavanoids Chalcone from a New Type of Brazillian Propolis, Sep. Purif. Technol., 77, 208-213.

3. Avila, H.P., Smania, E.F., Monache, F.D. and Junior, A.S., 2008, Structure-Activity Relationship of Antibacterial Chalcones, Bioorg. Med. Chem, 16, 9790-9794.

4. Li, Y.P., Yang, Y.C., Li, Y.K., Jiang, Z.Y., Hung, X.Z., Wang, W.G., and Gao, X.M., 2014, Prenylated Chalcones from Desmodium renifolium, Phytochem. Lett, 9, 41-45.

5. Sepvianti, W., 2016, Sintesis dan Uji Sitotoksisitas Turunan Kalkon terhadap Sel Kanker T47D, Hela dan WiDr secara In Vitro, Tesis, Pasca Sarjasa, Universitas Gadjah Mada.

6. Darmawan, A., Irawan, R, 2015, Mengenal CPOB untuk Produk Darah, JMJ, 3:111-118

7. Delaney M., Wendel S., Bercivitz R., Cid J, Cohn C.,Dunbar N.M., 2016, Transfusion Reactions: Prevention Diagnosis and Treatment, 388, 2824-2836.

8. Jasril., Teruna H.Y., Zamri A., Alfatos D., Yuslinda E., Nurulita Y., 2012, Sintesis dan Uji Antibakteri Senyawa Bromo Kalkon Piridin, Natur Indonesia, 14(3), 172-175. 